\title{
Pamukta Farklı Lateral Aralıkları ve Azotun Fertigasyonda Uygulama Sıklığının Lif Verimi ile Besin İçeriğine Etkisi
}

\author{
Neșe ÜZEN Öner ÇETIN*
}

Dicle Üniversitesi Ziraat Fakültesi Tarımsal Yapılar ve Sulama Bölümü DiYARBAKIR

*Sorumlu yazar e-mail (Corresponding author e-mail): oner_cetin@yahoo.com

Geliș tarihi (Received) : 05.12.2017

Kabul tarihi (Accepted): 12.12.2017

DOI : 10.21657/topraksu.410131

\section{Öz}

Bu araștırma, 201 1-2012 yılları arasında, damla sulama ile sulanan pamukta, farklı lateral aralığı ve azotun fertigasyonda farkı uygulama sıklığının lif verimi ile bitkilerdeki bazı makro ve mikro element içeriğine etkisi araștııılmıștır. Deneme, bölünmüș parseller deneme deseninde tesadüf bloklarına göre yürütülmüștür. Denemede, ana konular: $L_{1}$ : her sıraya bir lateral (lateral aralığı $0.70 \mathrm{~m}$ ), $L_{2}$ : her 2 sıraya bir lateral (lateral aralığı $1.40 \mathrm{~m}$ ) alt konular ise, $F_{1}$ : her sulamada (5 günde bir) $\mathrm{N}$ uygulaması $F_{2}$ :her 2 sulamada (10 günde bir) $N$ uygulaması $F_{3}: 1 / 4$ 'ünü ilk sulama ile ilk çiçeklenme arasında, 2/4'ünü ilk çiçeklenme ile ilk koza olușumu arasında, 1/4'ini de ilk koza olușumu ile son sulama arasında uygulamak șeklinde olmuștur. En yüksek ortalama lif verim (1855 $\left.\mathrm{kg} \mathrm{ha}^{-1}\right)$ her 2 sıraya 1 lateral ve her 2 sulamada bir fertigasyon uygulamasından elde edilmiștir. Buna göre, azotun 1/5'ini topraktan, kalanı her 2 sulamada (10 günde bir) eșit olarak (toplam 15-18 kez) fertigasyonla son sulama (\% 10 koza açımı) dönemine kadar uygulanmalıdır. Bitki yapraklarındaki total N 2011 yılında \% 1.66-3.05, 2012 yılında ise \% 1.92-3.01 arasında değișmiștir. Azot uygulama sıklığı arttıkça bitkilerdeki N içeriği de

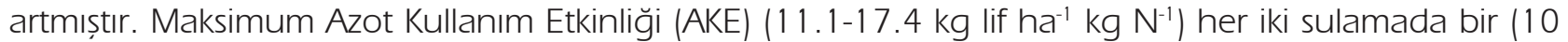
gün) fertigasyon uygulamasından elde edilmișir. Bitkilerdeki diğer makro ve mikro elemnetler ise P: \% 0.19-0.27, K: \% 1.56-1.72, Ca: \% 2.6-5.6, Mg: \% 0.13-0.37, Cu: 6.03-8.19 ppm, Zn: 3.55-15.81 ppm, Mn: 43.90-91.92 ppm ve Fe: 161-381 ppm olarak tespit edilmiștir. Buna göre Zn hariç mikro element yönünden bitkilerde bir eksiklik olmadığı tespit edilmiștir.

Anahtar Kelimeler: Azot, damla sulama, fertigasyon sıklığı, pamuk

\section{Effects of Different Lateral Spacings and Nitrogen Fertigation Frequencies on Lint Yield and Nutrient Content of Cotton}

\section{Abstract}

The aim of this study is to investigate the effects of different lateral spacing and frequencies of nitrogen $(\mathrm{N})$ fertigation on lint yield and content of some macro and micro elements for drip-irrigated cotton. The split-plot experimental design was applied in this research. The main plots; $L_{1}: 1$ lateral for each row (lateral space are $0.70 \mathrm{~m}$.), L $L_{2}: 1$ lateral for 2 rows (lateral space is $1.40 \mathrm{~m}$ ); Sub-plots were designed as different application $N$ frequencies; $F_{1}: N$ application for each irrigation (5 days) $F_{2}$ : $N$ application for each 2 irrigations ( 10 days) $F_{3}$ : $N$ application one-fourth of total $N$ between the first irrigation and the first flowering, two-fourth between the first flowering and the first boll formation, and one-fourth between the first boll formation and the last irrigation. The maximum cotton lint yield ( $\left.1855 \mathrm{~kg} \mathrm{ha}^{-1}\right)$ was obtained from the treatment of 1 lateral for 2 rows and each 2 irrigations ( 10 day). The total $\mathrm{N}$ content in cotton leaves ranged from 1.66 to $3.05 \%$ in 2011 and from 1.92 to $3.01 \%$ in 2012 depending on 
experimental treatments and growing stages of the plants. The uptake of $\mathrm{N}$ increased with an increasing frequency of $\mathrm{N}$ application. The maximum NUE (1 1.1-17.4 $\mathrm{kg}$ lint yied $\mathrm{ha}^{-1} \mathrm{~kg} \mathrm{~N}^{-1}$ ) was obtained for $\mathrm{N}$ fertigation every two irrigation cycles ( 10 days). The contents of other some macro and micro element in the cotton leaves were: P: 0.19-0.27 \%, K: 1.56-1.72\%, Ca: 2.6-5.6\%, Mg: 0.13-0.37\%, Cu: 6.03-8.19 ppm, Zn: 3.55-15.81 ppm, Mn: 43.90-91.92 ppm and Fe: 161-381 ppm. There were no significantly defficiency in terms of micro elemenst except Zn for cotton crop.

Key words: Cotton, drip irrigation, fertigation frequency, nitrogen

\section{GíRiș}

Pamuk ülkemizin ulusal ekonomi ve ihracat yönünden en önemli bir endüstri bitkisidir. Ülkemizde bölgeler arasında en yüksek ekiliș alanı Güneydoğu Anadolu Bölgesi'nde olup birinci (\% 50) siradadır.

Gelișen ve hızla yaygınlașan damla sulama gibi modern sulama sistemlerinde pamukta azotun sulama ile birlikte (fertigasyon) sulamanın hangi döneminde uygulanması gerektiği konularının araștırıması önemli hale gelmiștir. Yetișme mevsimi boyunca bitkideki $\mathrm{N}$ düzeyinin izlenmesi uygulanacak azotun tespitinde iyi bir yaklașım olabilir (Bronson vd., 2001; Chua vd., 20031.

Ravandere vd. (2003) pamukta geleneksel gübreleme ve fertigasyon uygulamasının etkilerini tespit etmek amacıyla yaptıkları araștırmada, deneme konuları, önerilen gübre dozunun \% 50, \% 75 ve \% 100'ü ve 3'e bölerek, yine fertigasyonda da $\% 50, \% 75$ ve $\% 100$ 'ü 6'ya bölerek uygulanmıștır. En yüksek kütlü pamuk verimi 6 kez uygulanan fertigasyon uygulamasından elde edilmiștir. Fertigasyon, geleneksel gübre uygulamasına göre verimi önemli düzeyde artırmıștır.

Hou vd. (2007) damla sulama ile sulanan pamukta, N fertigasyon uygulamasında, tüm sulamalar süresince her sulamanın bașlangııında uygulamanın daha etkin olduğunu tespit etmișlerdir.

Pamukta N kullanım etkinliğini geliștirmek için azotun uygulama zamanı en önemli konulardan birisi olduğu, azot intiyacının \% 22 sinin ilk çiçeklenmeden önce, kalanının $(\%$ 78) ise koza olușumu ile olgunlașma dönemi arasında karșılanması gerektiği belirtilmiștir (Livingston, 2007). Ayrıca, pamukta çiçeklenme döneminde azot kullanımı maksimum düzeyde olduğu bildirilmiștir (Silvertooth, 2001).
Oi vd. (2009) yaptıkları araștırma sonucuna göre, fertigasyonda N'in daha sık aralıklarla uygulamanın su ve besin elementi yarayıșlılığını artırarak verimi de artırdığı belirlenmiștir.

Bitkilerdeki bașta azot olmak üzere, makro ve mikro elementlerin tespit edilerek değerlendirilmesi bitki besleme açısından önemli bir rehberdir. Daha önce yapılan çalıșmalarda Görmüș (2002), yapraktan potasyum uygulamasında pamuk veriminin önemli derecede arttığını bildirmiștir. Efe ve Yarpuz (2011) pamukta Zn uygulamasının (toprak ve yapraktan) pamuk verim ve verim bileșenlerini etkilemediğini bildirmiștir. Bunda en büyük etkenin toprak kireç içereği ve pH'sının yüksek olmasına bağlamıșlardır. Topraklardaki bazı elementlerin P: 4.8 ppm, K:150 ppm, Fe: 0.97 ppm, Cu: 1.2 ppm, Mn: 9.97 ppm Zn:0.44 ppm olarak tespit etmișlerdir.

Damla sulama ile sulanan pamukta, azotun bitki kök bölgesine her sulamada verilmesinin daha uygun olacağı bașka araștıııcılar tarafından da belirtilmiștir (Bar-Yosef ve Sheikhoslami 1976; Papadopoulos 1988). Böylece, azot kaybı ya da derine yıkanmanın daha az olabileceği vurgulanmıștır (Miller vd., 1981; Papadopoulos 1985).

Bu araștırmada, damla sulama ile sulanan pamukta, farklı lateral aralıkları ve fertigasyonda $\mathrm{N}$ uygulama sıkığının pamukta lifverimi, azot kullanım etkinliği ile bitkideki makro ve mikro element içeriğine etkisi araștııımıștır. Bu araștırma 20112012 yılı vejetasyon süresince (2 yıl) Güneydoğu Anadolu Bölgesi'nde (Diyarbakır) yürütülmüștür.

\section{MATERYAL VE YÖNTEM \\ Deneme yeri toprak ve iklim özellikleri}

Topraklar, genel olarak düz ve düze yakın eğimli, ABC profilli zonal toprak grubuna girmektedir. Topraklar, tuzluluk ve drenaj sorunu 
Çizelge 1. Deneme yeri topraklarının bazı analiz sonuçları

Table 1. Some physical and chemical properties of the soil in the experimental site

\begin{tabular}{|c|c|c|c|c|c|c|c|c|c|c|c|}
\hline \multirow{2}{*}{$\begin{array}{c}\text { Toprak } \\
\text { derinliği } \\
\text { cm }\end{array}$} & \multirow[b]{2}{*}{$\mathrm{pH}$} & \multirow{2}{*}{$\begin{array}{l}\text { Org. } \\
\text { Mad. } \\
\%\end{array}$} & \multirow[b]{2}{*}{$\begin{array}{c}\text { Kireç } \\
\%\end{array}$} & \multirow[b]{2}{*}{ EC } & \multicolumn{4}{|c|}{ Toprak bünyesi } & \multirow{2}{*}{$\begin{array}{c}\text { Tarla } \\
\text { Kap. } \\
\mathrm{g} 100^{-1} \mathrm{~g}\end{array}$} & \multirow{2}{*}{$\begin{array}{c}\text { Solma } \\
\text { noktası } \mathrm{g} \\
100^{-1} \mathrm{~g}\end{array}$} & \multirow{2}{*}{$\begin{array}{l}\text { Hac. } \\
\text { Ağ. } \\
\mathrm{g} \mathrm{cm}^{-3}\end{array}$} \\
\hline & & & & & Kum \% & Silt \% & Kil \% & $\begin{array}{c}\text { Bünye } \\
\text { sınıfı }\end{array}$ & & & \\
\hline $0-30$ & 7.7 & 1.67 & 7.8 & 0.48 & 10 & 24 & 66 & C & 35.5 & 25.5 & 1.19 \\
\hline $30-60$ & 7.9 & 1.67 & 7.8 & 0.37 & 12 & 22 & 66 & C & 35.2 & 25.3 & 1.25 \\
\hline $60-90$ & 7.8 & - & 8.7 & 0.42 & 12 & 21 & 67 & C & 36.4 & 27.0 & 1.27 \\
\hline
\end{tabular}

Çizelge 2. Deneme konuları (Uzen and Cetin, 2016)

Table 2. The treatments in the experiment (Uzen and Cetin, 2016)

\begin{tabular}{|c|c|}
\hline $\begin{array}{l}\text { ANA KONULAR } \\
\text { (Lateral aralıkları) }\end{array}$ & $\begin{array}{c}\text { ALT KONULAR } \\
\text { (Fertigasyonda azotun uygulama sıklığı) }\end{array}$ \\
\hline $\begin{array}{l}\mathbf{L}_{1} \text { : Sıra aralığı eșit ve her sıraya bir lateral } \\
\text { (Sıra aralığı ve lateral aralığı } 0.70 \text { m) }\end{array}$ & $\mathbf{F}_{\mathbf{1}}$ : Her sulamada (5 günde bir) N uygulaması \\
\hline \multirow{2}{*}{$\begin{array}{l}\mathbf{L}_{2} \text { : Sıra aralığı eșit ve her } 2 \text { sıraya bir lateral } \\
\text { (Sıra aralığı } 0.70 \text {, lateral aralığı } 1.40 \text { m) }\end{array}$} & $\mathbf{F}_{\mathbf{2}}$ : Her iki sulamada bir (10 günde bir) N uygulamak \\
\hline & $\begin{array}{l}\mathbf{F}_{3} \text { : Azotun } 1 / 4^{\prime} \text { ünü ilk sulamada, } 1 / 2 \text { 'sini çiçeklenme } \\
\text { döneminde (\% 50) bir defada, diğer } 1 / 4 \text { 'ünü de ilk \% } \\
10 \text { koza olușumunda bir defada uygulamak }\end{array}$ \\
\hline
\end{tabular}

olmayan, potasyum ve kireç yönünden zengin, hafif alkali, fosfor ve organik madde içeriği ise düșüktür (Bukarlı, 2007).

Denemenin yürütüldüğü Dicle Üniversitesi Ziraat Fakültesi Deneme İstasyonundaki, deneme yeri topraklarının bazı fiziksel ve kimyasal analiz sonuçları Çizelge l'de verilmiștir. Buna göre deneme topraklarının kil içeriği çok yüksek olup, ağır bünyelidir. Bunun dıșında $\mathrm{pH}$, tuzluluk ve taban suyu ile ilgili önemli bir sorun bulunmamaktadır.

Yapılan sulama suyu analiz sonuçlarına göre sulama açısından kısıtlayıcı herhangi bir fiziksel ve kimyasal özelliklere rastlanılmamıștır.

Denemenin yürütüldüğü Diyarbakır iline ait deneme yıllarının ve uzun yıllara ait iklim verilerine göre, uzun yıllık ortalama yağıș miktarı 487 mm olup, bunun genellikle büyük bir kısmı kıș aylarında ve erken ilkbaharda yağmaktadır. Deneme yerine ait, minimum, maksimum ve ortalama sıcaklıklar, sırasıyla $2.8,28.4$ ve $15.8^{\circ} \mathrm{C}$ dir.

\section{Deneme yönetimi ve konular}

Deneme, tesadüf bloklarında bölünmüș parseller deneme desenine göre 3 tekrarlamalı olarak yürütülmüștür. Ana konuları farklı lateral aralıkları, alt konular ise fertigasyonda azotun farklı uygulama sıklığı șeklinde olmuștur (Çizelge 2).

\section{Makro ve mikro elementlerin tayini}

Bitkide $N$ ve diğer elementler için bitkinin çiçeklenme (\% 50) dönemi (Ağustos ayı bașlangıcı) esas alınarak örnekleme yapılmıș ve tespit edilmiștir. Bu dönemde, her alt parselde rastgele10 bitkide alınan yaprak örneklerinde analizler yapılmıștır (Chua vd., 2003). Bu amaçla toplanan yaprak örnekleri, çeșme suyu ve sonra da saf su ile yıkandıktan sonra, $65^{\circ} C^{\prime}$ de etüvde kurutulduktan sonra, bir agat değirmeninde öğütülerek analize hazır hale getirilmiștir. Bu örneklerde total $N$ analizleri Kheldal yöntemi ile tespit edilmiștir (Horneck ve Miller, 1998). Diğer makro ve mikro elementler ise Bremner (1965) ve Kacar (1972) tarafından verilen yöntemlere göre yapılmıștır.

\section{Diğer tarımsal uygulamalar}

Denemede damla sulama sistemi kullanılmıș olup, damlatıcı aralığı 0.40 m, damlatıcı debisi ise $4 \mathrm{I} \mathrm{h}^{-1}$ olarak uygulanmıștır (Yıldırım, 2003). Sulama suyu, deneme yerinde bulunan derin kuyudan çıkarılan ve biriktirme havuzundan güneș enerjisinden üretilen elektrik enerjisi ile çalıșan dalgıç pompa sayesinde sisteme verilmiștir.

Araștırmada, Stoneville-468 (ST 468) pamuk çeșidi kullanıımıștır. Bitki sıra aralığı $0.70 \mathrm{~m}$ ve sıra üzeri 0.15 m olarak ekilmiștir. 
Bitkilerin ekimi 2011 yılında 20 Mayıs'ta, 2012 yılında ise 10 Mayıs'ta yapılabilmiștir. Kütlü pamuk hasadı her iki deneme yılında da iki kez yapılmıș olup, ilk el hasat Eylül ayı sonunda, ikinci el hasat ise Ekim ayı ortalarında yapılımıștır.

Azotlu ve fosforlu gübrenin 1/5 oranları ekimle birlikte doğrudan toprağa kalanı ise fertigasyon yöntemi ile deneme konularında belirtildiği șekilde uygulanmıștır. Azotlu gübre $130 \mathrm{~kg} \mathrm{~N} \mathrm{ha}^{-1}$, fosforlu gübre ise toprak analiz sonuçları da esas alınarak $80 \mathrm{~kg} \mathrm{ha}^{-1} \mathrm{P}_{2} \mathrm{O}_{5}$ olarak eșit dozlar halinde fertigasyonla uygulanmıștır |Özer ve Dağdeviren, 1986; Özer, 1992; Karademir vd., 2005). Buna göre ekimle birlikte toplam uygulanacak net azot intiyacının 1/5'i ekimle birlikte doğrudan toprağa Diamonyum Fosfat (DAP, 18-46) gübresi uygulanmıștır. Kalanı ise deneme konularına göre, 19-5-5-mikro elementler içeren ticari toz (Compo Basaplant Blue) gübre fertigasyon tekniği ile uygulanmıștır. Bu gübre kaynağında ise, \% 19 total N, $1 \% 17.5^{\prime} \mathrm{i}$ Amonyum, \% 1.5'i Nitrat), \% 5'i suda çözünebilir $\mathrm{P}_{2} \mathrm{O}_{5}, \%$ ' $\mathrm{i}$ suda çözünebilir $\mathrm{K}_{2} \mathrm{O}$ ve eser miktarda ise, $\mathrm{B}, \mathrm{Cu}, \mathrm{Fe}, \mathrm{Mn}, \mathrm{Mo}, \mathrm{Zn}$ bulunmaktadır.

\section{Analiz ve değerlendirme}

Deneme sonucu elde edilen verilere her yıl varyans analizi uygulanmıștır. Varyans analiz sonuçlarına göre konular arasında, çoklu karșılaștırmayöntemi olan Duncantestiilekonuların birbirinden önemli derecede ayrı olup olmadıkları belirlenmiștir (Yurtsever, 1984). Bu arada, deneme konularında farklı lateral aralıkları ve fertigasyonda azotun bitkinin farklı dönemlerinde ve farklı sıklıkta uygulanması etkileșimi (interaksiyon) ve birbirinden bağımsız etkisinin olup olmadığı değerlendirilerek tartıșılmıștır.

\section{BULGULAR VE TARTIȘMA}

Farklı lateral aralıkları ve $\mathbf{N}$ fertigasyon sıklığının pamuk lif verimi ve azot kullanım etkinliğine (AKE) etkisi

Deneme yıllarına göre elde edilen ortalama lif verimleri ile NUE değerleri Çizelge 3'te verilmiștir. Denemenin 2011 yılı sonuçlarına göre lif verimleri, uygulanan deneme konularına bağlı olarak 948 - $1441 \mathrm{~kg} \mathrm{ha}^{-1}$ arasında değișmiștir. Buna göre; en düșük verim (948 $\mathrm{kg} \mathrm{ha}^{-1}$ ) her sıraya 1 lateral uygulanan ve her 2 sulamada 1 ( 10 günde 1) kez azotun uygulandığı fertigasyon uygulamasından, en yüksek verim (1441 $\mathrm{kg} \mathrm{ha}^{-1}$ ) ise, her 2 sıraya 1 lateral bulunanan ve yine her iki sulamada bir (10 günde 1) kez azotun uygulandığı fertigasyon uygulamasından elde edilmiștir (Çizelge 3).

2011 yılı için yapılan varyans analiz sonuçlarına göre, fertigasyon sıklığının ve lateral aralığının verim üzerinde etkisi ayrı ayrı önemli bulunmamıștır. Ancak, her iki uygulamanın etkileșimi (interaksiyonu) istatistiksel bakımdan \% 5 hata düzeyinde önemli bulunmuștur. Bunun anlamı, hem fertigasyon sıklığı hem de lateral aralığı birlikte verime etki etmiștir. Buna göre, her iki sıraya bir lateral uygulaması ile fertigasyon sıklığı uygulaması birlikte verimi artırmıștır. Buna göre uygulamalar arasındaki fark interaksiyon verileri üzerinde yapılan Duncan testi sonuçları da aynı veriler üzerinde gösterilmiștir (Çizelge 3).

Denemenin 2012yılı sonuçlarınagöre lifverimleri, uygulanan deneme konularına bağlı olarak 1411 - $2268 \mathrm{~kg} \mathrm{ha}^{-1}$ arasında değișmiștir. Buna göre en düșük verim $\left(1411 \mathrm{~kg} / \mathrm{ha}^{-1}\right)$ her sıraya bir lateral uygulanan ve her sulamada azotun uygulandığı (beș günde bir) fertigasyon uygulmasından, en yüksek verim (2268 kg ha-1) ise, her iki sıraya bir

Çizelge 3. Deneme konularına göre pamuk lif verimi ve azot kullanım etkinliği (AKE)

Table 3. Cotton lint yield and nitrogen use efficiency according to the treatments

\begin{tabular}{|c|c|c|c|c|c|c|c|}
\hline \multirow{2}{*}{\multicolumn{2}{|c|}{ Deneme konuları }} & \multicolumn{3}{|c|}{2011} & \multicolumn{3}{|c|}{2012} \\
\hline & & $\begin{array}{c}\text { Çırıçır } \\
\text { randımanı } \\
\%\end{array}$ & $\begin{array}{l}\text { Lif verimi } \\
\mathrm{kg} \mathrm{ha}^{-1}\end{array}$ & $\begin{array}{c}\text { AKE } \\
\text { Kg lif kg N} \mathrm{N}^{-1} \\
\mathrm{ha}^{-1}\end{array}$ & $\begin{array}{c}\text { Çrıçır } \\
\text { randımanı } \\
\%\end{array}$ & $\begin{array}{l}\text { Lif verimi } \\
\mathrm{kg} \mathrm{ha}^{-1}\end{array}$ & $\begin{array}{c}\text { AKE } \\
\text { kg lif } k g N^{-1} \\
\mathrm{ha}^{-1}\end{array}$ \\
\hline \multirow{3}{*}{$\mathrm{L}_{1}$} & $F_{1}$ & 42,5 & $1026 \mathrm{~cd}$ & 7,9 & 45,9 & 1411 & 10,9 \\
\hline & $\mathrm{F}_{2}$ & 42,9 & $931 d$ & 7,2 & 44,4 & 1810 & 13,9 \\
\hline & $\mathrm{F}_{3}$ & 43,2 & $948 d$ & 7,3 & 46,3 & 1702 & 13,1 \\
\hline \multirow{3}{*}{$\mathrm{L}_{2}$} & $F_{1}$ & 43,8 & $1281 \mathrm{~b}$ & 9,9 & 45,0 & 1665 & 12,8 \\
\hline & $\mathrm{F}_{2}$ & 43,1 & 1441 a & 11,1 & 46,3 & 2268 & 17,4 \\
\hline & $\mathrm{F}_{3}$ & 43,5 & 1207 bc & 9,3 & 43,5 & 2017 & 15,5 \\
\hline
\end{tabular}

\footnotetext{
*: Duncan çoklu karșılaștırma testine göre aynı harf grupları arasında istatistiksel olarak fark yoktur.
} 
Çizelge 4. Denemede ana ve alt konuların lif verimine ayrı ayrı etkisi (2012)

Table 4. The effects of main and sub treatments on lint yield (2012)

\begin{tabular}{cccc}
\hline $\begin{array}{c}\text { Farklı lateral } \\
\text { aralıkları }\end{array}$ & Verim $\mathrm{kg} \mathrm{ha}^{-1}$ & Azotun fertigasyonda farklı uygulama sıklığı & Verim kg ha $^{-1}$ \\
\hline $\mathrm{L}_{1}$ & $1641 \mathrm{~b}^{*}$ & $\mathrm{~F}_{1}$ & $1538 \mathrm{~b}^{*}$ \\
$\mathrm{~L}_{2}$ & $1983 \mathrm{a}$ & $\mathrm{F}_{2}$ & $2039 \mathrm{a}$ \\
& & $\mathrm{F}_{3}$ & $1859 \mathrm{ab}$ \\
\hline
\end{tabular}

*: Farkı harf grupları, Duncan gruplandırmasına göre \% 1 hata düzeyinde istatistiksel bakımdan verim değerlerinin farklı olduğunu göstermektedir.

lateral bulunan ve yine her iki sulamada bir (on günde bir) kez azotun uygulandığı fertigasyon uygulamasından elde edilmiștir (Çizelge 3).

Yapılan varyans analiz sonuçlarına göre, lateral aralığı ve fertigasyon sıklığı pamuk lif verimini ayrı ayrı \% 1 hata düzeyinde etkilemiștir. Buna göre, her iki sıraya bir lateral uygulamasında verim daha yüksek gerçekleșmiștir. Benzer șekilde, yine her iki sulamada bir (on günde bir) kez azotun uygulandığı fertigasyon uygulamasından maksimum verim elde edilmiștir. Konular arasında interaksiyon (etkileșim) bulunmamıștır. Buna göre ana faktör (lateral aralığı) ve alt faktör (azotun fertigasyonla uygulama sıklığı) verileri ayrı ayrı değerlendirilerek Duncan testine tabi tutulmuș ve sonuçlar Çizelge 4'te verilmiștir.

2012 yllı bulgularına göre, her iki sıraya bir lateral uygulaması en yüksek verimi sağlamıș olup, her sıraya bir lateral uygulaması ile ayrı ayrı grupte yer almıștır. Azotun fertigasyonda farklı uygulama sıklığı konusunda ise, en yüksek verim her iki sulamada bir uygulama konusundan elde edilmiș olup, diğer uygulamalar da ayrı gruplarda yer almıștır (Çizelge 4).

Denemede fertigasyon uygulama yöntem ve/ veya ekipmanı basınç farklılığ easına dayalı bypass sistemi ile her sulamadaki (beș günde bir) fertigasyon uygulamasında çok küçük miktarlarda gübre uygulandığından, bitki kök bölgesine homojen bir dağılımın olması zordur. Bașka bir ifade ile toplam uygulanan azotlu gübrenin her beș günde bir uygulama konusunda daha fazla sayıya bölünerek ve daha az miktarlarda uygulanması, bitkilerin azotlu gübreden yararlanma etkinliği diğer her 10 günde bir uygulamaya göre daha az olmuș olabilir. Aujla vd. (2005), de fertigasyonun her bir uygulamasında azot düzeyinin azaltılması verimi de azalttığını tespit etmiștir.

Pamukta azot kullanım etkinliğini geliștirmek için azotun uygulama zamanı en önemli konulardan birisi olduğu (Livingston, 2007) ve ayrıca, pamukta çiçeklenme döneminde azot kullanımının maksimum düzeyde olduğu bildirilmiștir (Silvertooth, 2001).

Damla sulama ve fertigasyon diğer sistemlerle kıyaslandığında farklı aralıklarda düșük dozlarda gübre uygulanması sonucu besinlerin yıkanma riskini azaltmaktadır. Ravandere vd. (2003) pamukta fertigasyon uygulamasında, gübrenin 3 ve 6'ya bölünerek uygulamasında, en yüksek kütlü pamuk verimi 6 kez uygulanan fertigasyon uygulamasından elde edilmiștir. Oi vd. (2009) yaptıkları araștırma sonucuna göre, fertigasyon sıklığı (her beș günde bir uygulama) pamuk verimini ve kuru madde miktarını artırmıștır. Hou vd. (2007) pamukta fertigasyonla ilgili olarak farklı uygulamaları kıyaslamıșlardır. Elde edilen sonuçlara göre, sulamanın bașında azotu uygulamak kuru madde miktarını, azot alımını ve azot kullanım etkinliğini artırmıștır. Damla sulama ile sulanan pamukta, azotun bitki kök bölgesine her sulamada verilmesinin daha uygun olacağı belirtilmiștir (Bar-Yosef ve Sheikhoslami, 1976; Papadopoulos, 1988). Böylece, azot kaybı ya da derine yıkanmanın daha az olabileceği vurgulanmıștır (Miller vd., 1981; Papadopoulos, 1985).

AKE deneme yıllarına bağlı olarak $7.2-17.4 \mathrm{~kg}$ lif $\mathrm{kg} \mathrm{N}^{-1} \mathrm{ha}^{-1}$ arasında değișmiștir. Maksimum AKE lif veriminde olduğu gibi her iki sulamada bir olan (on günde bir) fertigasyon uygulamasından elde edilmiștir (Çizelge 3). Benzer șekilde Rochester vd. (2009) pamukta NUE'nin 10.9 - 12.9 arasında değiștiğini ve bu durumda azotun yeterli olduğunu bildirmișlerdir.

\section{Deneme yeri topraklarında bazı makro ve mikro element düzeyleri}

Deneme yeri topraklarında yapılan bazı makro ve mikro element analiz sonuçları Çizelge 5'te verilmiștir. Buna göre toprak pH'sı 7.7 - 7.9 arasında, organik madde (OM) içeriği ise \% 
Çizelge 5. Deneme yeri topraklarında bazı makro ve mikro element düzeyleri

Table 5. Some macro and micro element levels in the soil of experimental site

\begin{tabular}{cccccccc}
\hline $\begin{array}{c}\text { Toprak derinliği } \\
\text { cm }\end{array}$ & $\mathrm{P}$ & $\mathrm{K}$ & $\mathrm{Fe}$ & $\mathrm{Cu}$ & $\mathrm{Zn}$ & $\mathrm{Mn}$ & $\begin{array}{c}\text { Total N } \\
\%\end{array}$ \\
\hline $0-30$ & 5.5 & 408 & 5.24 & 1.44 & 1.16 & 5.51 & 0,083 \\
$30-60$ & 6.9 & 319 & 4.98 & 1.46 & 0.60 & 4.74 & 0,083 \\
\hline
\end{tabular}

1.67 olup düșüktür. $P$ ve Zn içerikleri de düșük olup, diğer Fe, Cu ve $\mathrm{Mn}$ ise (Follet ve Lindsay, 1970; Ankerman ve Large, 1977)'de verilen eșik değerlere göre yüksek bulunmuștur.

Toprak analiz sonuçlarına göre bitki besleme açısından P, OM ve total N'nin yetersiz olduğu söylenebilir.

Toprakların pH, kil ve kireç içeriğinin yüksek olması bitki besleme açısından özellikle mikro elementlerin alınabilirliği bakımından olumsuz etki gösterebilir. Çünkü besin elementlerinin topraktan absorbsiyonu toprak $\mathrm{pH}$ 'sı, tekstürü ve $\mathrm{OM}$ içeriğine bağlıdır. Bunlardan toprak pH'sı besin elementlerinin yarayıșlılığını etkileyen en önemli toprak özelliğidir. Çünkü yüksek pH değerlerinde mikro elementler daha az yarayıșlıdır (Gardiner ve Miller, 2008). Birçok mikro element toprak pH'sı arttıkça daha az çözünür hale gelebilmekte, böylece bitkiye olan yarayıșlılığı azalmaktadır. Örneğin, pH arttıkça Zn, Mn ve Cu'nun yarayıșlılığı azalmaktadır. Buna göre deneme yeri topraklarının özellikle Zn yönünden neden eksik olduğunu da göstermektedir.

\section{Bitkide total $\mathbf{N}$ ve diğer elementler}

Bitki yapraklarındaki total $N$ değerleri incelendiğinde bu değerler 2011 yılı için \%
2.59-2.88, 2012 yılında ise \% 2.31-2.61 arasında değișmiștir (Çizelge 6). Denemenin 2012 yılı verilerine göre, total $N$ değerlerine azotun fertigasyonla uygulama sıklığının etkis istatistiksel olarak \% 5 hata düzeyinde etk ettiği tespit edilmiștir (Çizelge 6). Diğer yıllarda ve dönemlerde bitki total $\mathrm{N}$ içerikleri arasında istatistiksel olarak önemli bir fark bulunmamıștır. Yapılan değerlendirmede, 2012 yılı için en yüksek azot içeriği her 2 sulamada bir uygulanan fertigasyon uygulamasından elde edilmiștir. Buna göre, verim sonuçlarına benzer șekilde, her 2 sulamada bir yapılan azot fertigasyon uygulamasının bitki yaprak total $\mathrm{N}$ içeriğinin de daha yüksek olmasını sonuçlamıștır. Her sulamada uygulanan fertigasyonda, aynı miktar azotun her 2 sulamaya göre kıyaslandığında daha fazla doza bölünmesi sulama suyunda çok az miktarlarda besin elementi bulunması muhtemelen yeterli homojenlikte ve yeterli miktarda azotun bitki kök bölgesine ulașmadığına bağlanabilir. Bu durum ise, önceki bölümlerde açıklandığı üzere, her 2 sulamada bir fertigasyon durumunda nispi olarak daha yüksek dozda azot uygulanması, azotun bitkiler tarafından daha etkin olarak kullandığını buna bağlı olarak da verimin de daha yüksek olmasına neden olduğu söylenebilir.

Çizelge 6. Deneme konularına göre bitkide total N miktarı (\%)

Table 6. The total $N(\%)$ according to experimental treatments

\begin{tabular}{|c|c|c|c|}
\hline Ana Parseller & Alt Parseller & 2011 & 2012 \\
\hline \multirow{3}{*}{$\mathbf{L}_{1}$} & $F_{1}$ & 2,43 & 2,39 \\
\hline & $\mathbf{F}_{2}$ & 2,58 & 2,52 \\
\hline & $\mathbf{F}_{3}$ & 2,45 & 2,42 \\
\hline \multirow{3}{*}{$\mathbf{L}_{2}$} & $F_{1}$ & 2,68 & 2,31 \\
\hline & $F_{2}$ & 2,88 & 2,61 \\
\hline & $F_{3}$ & 2,59 & 2,40 \\
\hline \multicolumn{2}{|c|}{ Fertigasyonda azotun farklı uygulama sıklığı } & \multicolumn{2}{|c|}{2012} \\
\hline \multicolumn{2}{|c|}{$F_{1}$} & \multicolumn{2}{|c|}{$2,35 \mathrm{b*}$} \\
\hline \multicolumn{2}{|c|}{$F_{2}$} & \multicolumn{2}{|c|}{2,57 a } \\
\hline \multicolumn{2}{|c|}{$\mathbf{F}_{3}$} & \multicolumn{2}{|c|}{2,41 а } \\
\hline
\end{tabular}

\footnotetext{
*: Farkıı harf grupları, Duncan gruplandırmasına göre \% 5 hata düzeyinde istatistiksel bakımdan değerlerin farklı olduğunu
} göstermektedir. 
Genel olarak bitkideki azot düzeyleri incelendiğinde, bitkide yeterli düzeyde olmadığı söylenebilir. Çünkü, Reuter ve Robinson (1986) pamukta N düzeyinin \% 3.75-4.5, Mitchell ve Baker (2009) ise geç çiçeklenme döneminde N düzeyinin \% 3.0-4.0 arasında olması gerektiğini bildirmiștir. Bunun bir nedeni toplamda uygulanan azotun az olduğu düșünülebilir. Ancak önceden yüzey sulama ve geleneksel gübreleme çalıșmalarında pamuk azot ihtiyacının $130 \mathrm{~kg} \mathrm{~N} \mathrm{ha-1} \mathrm{olduğu}$ bildirilmiștir (Özer, 1992; Karademir vd., 2005). Ancak, fertigasyonun üstünlüklerinden birisi de gübre kullanım etkinliğinin yüksek olması verimin de yüksek olmasını sağlayabilmektedir. Bu durum ise, fertigasyon uygulamalarında muhtemelen azotlu gübre intiyacı geleneksel yöntemlerden farklı daha doğrusu daha yüksek olabilir. Ayrıca bu durum yeni gelișen yüksek verim potansiyeline sahip pamuk ceșitlerine de bağlıdır. Diğer bir konu ise, fertigasyon uygulama yöntem ve aygıtının etkinliği de bunda rol oynamıș olabilir. çünkü basınç farklılı̆ı yöntemi uygulanarak azotun uygulanmasında, sulama suyundaki gübre konstrasyonundaki yüksek değișkenlik ve her uygulamadaki düșük doz, muhtemelen bitki kök bölgesinde de homojen bir gübre dağılımı sağlamamıș olabilir.

Pamuk bitkisine ait, çiçeklenme döneminde yapılan yaprak analiz sonuçlarına göre kimi makro ve mikro besin elementlerinin düzeyi yıllara göre Çizelge 7'de verilmiștir. Deneme konularının incelenen bu besin elementleri üzerinde istatistiksel olarak bir etkisi olmamıștır.

Pamuk yapraklardındaki makro ve mikro elementlerin yeterli düzeyleri, Reutor ve Robinson (1986) tarafından, $\mathrm{P} \%$ 0.3-0.5, $\mathrm{K} \% 2-3$, Ca \% 2.25-3.00, Mg \% 0.5-0.9, Cu 5-25 ppm, Zn 20-
60 ppm, Mn 50-350 ppm ve Fe 50-250 ppm arasında olması gerektiği belirtilmiștir. Bunun yanında, Mitchell ve Baker (2009) ise, bitkinin geç çiçeklenme döneminde P \% 0.15-0.6, K \% 0.75-2.5, Ca \% 2.0-4.00, Mg \% 0.3-0.9, Cu 5-25 ppm, Zn 20-300 ppm, Mn 10-400 ppm ve Fe 50300 ppm arasında olabileceğini bildirmiștir.

Bulgulara göre, Mitchell ve Baker (2009)'a göre, makro elementlerden P, K ve Ca yeterli Mg ise yetersizdir. Mikro elemetlerden ise, $Z n$ yetersiz, Fe, Cu ve Mn ise yeterli görünmektedir. Çinkonun yetersiz olması muhtemelen deneme topraklarının kireç içeriğinin nispi olarak yüksek olmasına bağlanabilir. Bitkilerdeki Ca içeriğinin yüksekliği de bu durumu göstermektedir. Cünkü bitkilerdeki Ca içeriği \% 2.3-5.6 arasında değișmiștir. Öte yandan, Kızılgöz vd. (201 1) aynı bölgede pamukta yaptıkları araștırmada da pamuk bitkilerinde Zn beslenmesinin kısmen yetersiz olduğunu tespit etmiștir. Erdal vd. (2017) İzmir-Menemen'de yaptığı araștırmada, pamuk yapraklarındaki makro ve mikro element içeriklerini tespit etmișlerdir. Buna göre geleneksel yetiștirilen pamuk yapraklarında $\mathrm{N} \%$ 2.93, P \% 0.21, K \% 1.35, Ca \% 1.19 ve Mg \% 0.19, mikro elementlerden Fe 178 ppm, Cu 9.35 ppm, Mn 87.0 ppm ve Zn 11.2 ppm olarak tespit edilmiștir. Organik pamukta ise $\mathrm{N} \% 2.82$, $\mathrm{P}$ $\%$ 1.37, Ca \% 0.96, Mg \% 0.15, Fe 146 ppm, Cu 7.82 ppm, Mn 60.6 ppm ve Zn 9.6 ppm olarak tespit edilmiștir.

Bu sonuçlara göre araștırma bölgesinde, özellikle pamuk Zn beslenmesi ile ilgili yeni araștırmaların yapılmasında yarar olacaktır.

\section{SONUC}

Fertigasyon uygulama yöntem ve aygıtı (basınç farklığı, by-pass tank sistemi) dikkate alınarak,

Çizelge 6. Deneme konularına göre bitkide total N miktarı (\%)

Table 6. The total $N(\%)$ according to experimental treatments

\begin{tabular}{|c|c|c|c|c|c|c|c|c|c|c|c|c|c|c|c|}
\hline \multirow{2}{*}{$\begin{array}{l}\text { Ana } \\
\text { Konu }\end{array}$} & \multirow{2}{*}{$\begin{array}{l}\text { Alt } \\
\text { onular }\end{array}$} & \multicolumn{2}{|c|}{$\mathrm{P}(\%)$} & \multicolumn{2}{|c|}{$\mathrm{K}(\%)$} & \multicolumn{2}{|c|}{ Ca $(\%)$} & \multicolumn{2}{|c|}{$\mathrm{Mg}(\%)$} & \multicolumn{2}{|c|}{ Fe (ppm) } & Cu (ppm) & \multicolumn{2}{|c|}{ Zn (ppm) } & Mn (ppm) \\
\hline & & 2011 & 2012 & 2011 & 2012 & 2011 & 2012 & 2011 & 2012 & 2011 & 2012 & 20112012 & 2011 & 2012 & 20112012 \\
\hline \multirow{3}{*}{ Ll } & $\mathrm{F} 1$ & 0,25 & 0,26 & 1,56 & 1,56 & 2,3 & 5,6 & 0,37 & 0,23 & 381 & 216 & $6,48 \quad 8,19$ & 5,85 & 15,81 & $91,9271,35$ \\
\hline & F2 & 0,19 & 0,27 & 1,72 & 1,72 & 3,7 & 4,1 & 0,19 & 0,21 & 161 & 178 & $6,03 \quad 6,56$ & 13,70 & 13,27 & $54,8546,38$ \\
\hline & F3 & 0,25 & 0,26 & 1,56 & 1,56 & 2,7 & 4,5 & 0,12 & 0,20 & 171 & 217 & $7,51 \quad 6,24$ & 3,55 & 6,90 & $69,5543,90$ \\
\hline \multirow{3}{*}{ L2 } & $\mathrm{F} 1$ & 0,27 & 0,25 & 1,72 & 1,56 & 4,0 & 2,7 & 0,20 & 0,13 & 178 & 171 & $6,54 \quad 7,51$ & 13,17 & 3,55 & $46,3869,55$ \\
\hline & $\mathrm{F} 2$ & 2,20 & 0,19 & 1,56 & 1,72 & 4,5 & 3,7 & 0,20 & 0,19 & 217 & 161 & $6,24 \quad 6,03$ & 6,90 & 13,70 & $43,8754,85$ \\
\hline & F3 & 0,26 & 0,25 & 1,56 & 1,56 & 5,6 & 2,6 & 0,23 & 0,13 & 216 & 171 & $8,197,20$ & 15,81 & 3,337 & $71,5568,80$ \\
\hline
\end{tabular}


sulama sezonu boyunca her sulama yerine her 2 sulamada bir toplam azotlu gübrenin eșit dozlara bölünerek kozaların açmaya bașladığı (yaklașık \% 10) döneme kadar uygulanması pamuk lif (1855 kg ha' ${ }^{-1}$ verimi maksimize etmiștir.

Hem verim hem de bitkilerin yaprak örneklerindeki total $N$ değerlerine göre verilen toplam azotlu gübre miktarının yeterli olmadığı kușkusu ortaya çıkmıștır. Çünkü her ne kadar fertigasyon genel anlamda gübrede tasarruf sağlasa da, fertigasyonda, birim gübre uygulamalarında verimdeki artıș nedeniyle toplamda bazen geleneksel olarak gerekli gübre miktarından daha fazla gübre ihtiyacı olabilmektedir. Ayrıca verim potansiyeli yüksek yeni pamuk çeșitleri, fertigasyon tekniğinde hem toplamda uygulanan azot miktarı, hem de gübrelerin farklı fertigasyon uygulama teknikleri gözönüne alınarak yeni araștırmaların yapılmasında yarar olacaktır.

\section{TEȘEKKÜR}

Bu makaledeki bazı veriler Dicle Üniversitesi Bilimsel Araștırma Projeleri Koordinatörlüğü tarafindan desteklenen 10-ZF-166 No'lu proje sonuç raporu verilerinden olușmaktadır. Makalenin yalnız bitki beseleme ile ilgili bölümü yalnız özet (abstract) olarak, World Cotton Research Conference - 6, Goiânia - Goiás, Brazil, 2 - 6 May, 2016 isimli confrensta sunulmuștur. Ayrıca yalnız lif verimleri Uzen ve Cetin (2016) yayınında da yer almıștır.

\section{KAYNAKLAR}

Ankerman D, Large R, (1977). Soil and plant analysis. A\&L Agricultural Laboratories, Memphis, Tn, USA. 82 pp.

Aujla MS, Thind HS, Buttar GS (2005). Cotton yield and water use efficiency at various levels of water and $\mathrm{N}$ through drip Irrigation under two methods of planting. Agricultural Water Management, 17(2): 167-169.

Bar-Yosef B, Sheikhoslami MR (1976). distribution of water and Ions in soils ırrigated and fertilized from a trickle source. Soil Sci Soc Am J, 40:575-582.

Bremner JM (1965). Organic forms of nitrogen. In: Black, C.A. (Ed.). Methods of Soil Analysis. Part 2 American Society of Agronomy, Madison, Wl, pp. 1238 1255.

Bronson KF, Onken AB, Keeling JW, Booker JD, Torbert HA (2001). Nitrogen response in cotton as affected by tillage system and irrigation level. Soil Sci. Soc. Am. J. 65: 11531163.

Bukarlı MN (2007). Diyarbakır koșullarında kükürt uygulamasının pamuğun verim ve kalite özelliklerine etkisi. c..Ü. Fen Bilimleri Enst., Yüksek Lisans Tezi, Adana, s. 79.
Chua TT, Bronson KF, Booker JD, Keeling JW, Mosier AR, Bordovsky JP, Lascano RJ, Green CJ, Segarra E (2003). InSeason nitrogen status sensing in irrigated cotton I. Yields and Nitrogen-15 Recovery Soil Sci. Soc. Am. J. 67: 14281438.

Efe L, Yarpuz E (2011). The effect of zinc application methods on seed cotton yield, lint and seed quality of cotton (Gossypium hirsutum L.) in east Mediterranean region of Turkey. African Journal of Biotechnology. 10: 8782-8789.

Erdal Ü, Sökmen Ö (2017). Organik ve konvansiyonel pamuk yetiștiriciliğinde toprak özelliklerinin karșılaștırıması. I.Uluslararası Organik Tarım ve Biyoçeșitlilik Sempozyumu, Bayburt Turkey, 27-29 Eylül 2017.

Follet RH, Lindsay WL (1970). Profile distribution of zinc, iron, manganese and copper in Colorado soils. Colorado Exp. Station Tech. Bull. 1 10. USA.

Gardiner DT, Miller RW (2008). Soils in Our Environment. 11 th Edition, Pearson/Prentice Hall, Upper Saddle Hill, Ne Jersey, USA.

Gormus O (2002). Effects of rate and time of potassium application on cotton yield and quality in Turkey. J. Agron. Crop Sci. 188: 382-388.

Horneck, DA, Miller RO (1998) .Determination of total nitrogen in plant tissue. In: Kalra, Y.P., Eds., Handbook of Reference Methods for Plant Analysis, Soil and Plant Analysis Council, Inc. CRC Press, Boca Raton, pp.75-83.

Hou Z, Li P, Li B, Gong J, Wang, Y (2007). Effects of fertigation scheme on $\mathrm{N}$ uptake and $\mathrm{N}$ use efficiency in cotton. Plant Soil290: 115-126.

Kacar B (1972). Bitki ve toprağın kimyasal analizleri: II, bitki analizleri. Ankara Üniv. Zir. Fak. Yayınları, No: 453, Ankara.

Karademir C, Karademir E, Doran I, Altıkat A (2005). Diyarbakır ekolojik koșullarında farkı azot ve fosfor uygulamalarının pamukta verim ve lif teknolojik özelliklerine etkisi. GOÜ Ziraat Fak. Dergisi, 22(1), 55-61

Kızılgöz İ, Sakin EA, Rıza Ö, Almaca A (2011). Tuzlu ve tuzsuz topraklarda yetiștirilen pamuk (gossypium hirsutum L.) bitkisinin makro ve mikro element kapsamlarının karșılaștırıması. Uludağ Üni. Ziraat Fak. Dergisi 25(2):19-30.

Livingston S (2007). Correcting nitrogen deficiencies in cotton with urea based products Urea. http://agfacts.tamu. edu/D1 1/Extension (19.04.2007)

Miller R, Rolston DE, Rauschkolb RS, Wolfe DE (1981) Labeled $N$ uptake by drip-irrigated tomatoes. Agron J 73: 256-270

Mitchell CC, Baker WH (2009). Reference sufficiency ranges, field crops: cotton. reference sufficiency ranges for plant analysis in the southern region of the united states. Southern Cooprative Series Bulletin, 394. NC

Özer MS (1992). Harran ovası koșullarında pamuğun fosforlu gübre isteği, Köy Hizmetleri Șanlıurfa Araștırma Enstitüsü Müdürlüğü Yayınları Genel Yayın No: 71, Rapor Seri No: R-47, Șanlıurfa.

Özer SM, Dağdeviren i (1986). Harran ovası koșullarında pamuğun azotlu gübre isteği. Köy Hizmetleri Araștırma Enstitüsü Yayınları, Yayın No:25, Rapor Serisi No: 17, Șanlıurfa. 
Papadopoulos I (1985). Constant feeding of field-grown tomatoes irrigated with sulphate water. Plant Soil 88: $231-$ 236.

Papadopoulos I (1988). N fertigation of trickle-irrigated potato. Fert Res 16: 157-167.

Qi T, Hou Z, Ye J, Ruan M, Lu X, Hao ZZ, Shi L (2009). Effects of nitrogen rate and fertigation frequency on nitrogen uptake and yield of hybrid cotton. Cotton Science 2009 प21(5)378-382.

Ravandere HN, Hadole SS, Sarap PA, Patil DB (2003). Studies fertilizer and fertigation impact seed cotton yield and fertilizer use economy. Annals of Plant Physiology. Vol:17, IS-2 PS. 203-204

Reuter DJ, Robinson JD (1986). Plant analyisis: An interpretation manuel. Inkata Press, Melbourne.

Rochester I, Ceeney S, Maas S, Gordon R, Hanna L, Hill $J(2009)$. Monitoring nitrogen use efficiency in cotton crops. The Australian Cotton Grower, April-May 2009, 42-43.
Silvertooth JC (2001). Nitrogen management for cotton. University of Arizona, Cooperative Extension pub. AZ 1200. (http://ag.arizona.edu/crops/cotton/soilmgt/nitrogen_ management.html)

Uzen $N$, Cetin O (2016). Effects of nitrogen fertigation frequency on yield and nitrogen retention in drip-irrigated cotton. Journal of Plant Nutrition Volume 39, 2016 - Issue 14 p.2126-2135

Yıldırım O (2003). Sulama sistemlerinin tasarımı. Ankara Üni. Ziraat Fakültesi, Yayın No: 1536, Ders Kitabı:489, Ankara, $348 \mathrm{~S}$.

Yurtsever N (1984). Deneysel istatistik metotları. T.C. Tarım Orman ve Köyișleri Bakanlığı, Köy Hizmetleri Genel Müdürlüğü, Toprak ve Gübre Araș. Enst. Müd. Yayınları, Gen Yayın No: 121, Teknik Yayın No: 56, Ankara 